\title{
Phosphorus in Soils of Temperate Forests: Linkages to Acidity and Aluminum
}

\section{Michael D. SanClements*}

Institute of Arctic and Alpine Research Univ. of Colorado

1560 30th St.

Boulder, CO 80303

Ivan J. Fernandez

Dep. of Plant, Soil, and Environ. Sci.

Univ. of Maine

Orono, ME 04469

\section{Stephen A. Norton}

Dep. of Earth Sciences

Univ. of Maine

Orono, ME 04469
We used P fractionation techniques to study the accumulation, mobilization, and availability of soil P in six watersheds of the eastern United States and Europe, two of which included paired long-term acidification experiments. Although total soil P concentrations varied widely among these watersheds, the proportions of $\mathrm{P}$ fractions were relatively uniform. The mean for the $\mathrm{P}$ fraction operationally defined as being associated with $\mathrm{Al}$ in the reference watersheds was $71 \%$ of total extractable $\mathrm{P}(\mathrm{SE} \leq 1 \%)$. Experimental whole-watershed acidification resulted in significant depletion of Al-P concentrations from the upper mineral soil in treated watersheds due to the dissolution of Al hydroxide by acidic solutions traveling along shallow flow paths. Acidic soil solutions mobilize both $\mathrm{Al}$ and $\mathrm{P}$, leading to P depletion from the Al-P fraction in the mineral soils. Across this suite of watersheds, lower $\mathrm{pH}$ appears to decrease $\mathrm{Al} / \mathrm{P}$ ratios in the Al-P fraction of these mineral soils through changes in Al solubility. Biocycling in these forests can play a critical role in linking subsurface mineral soil $\mathrm{P}$ to surface $\mathrm{O}$ horizon available $\mathrm{P}$. In this study, sites with the lowest mineral subsoil Al/P ratios generally had the lowest mineral soil $\mathrm{pH}$ values and the highest $\mathrm{O}$ horizon available $\mathrm{P}$ concentrations. The net effect was to leave subsoil $\mathrm{P}$ more bioavailable at the lower $\mathrm{pH}$ values because of a lower $\mathrm{Al} / \mathrm{P}$ ratio in the mineral subsoil at the $\mathrm{pH}$ range of 3.1 to 4.6 found in this study. These results suggest that changes in soil acidity due to management, air pollutants, or pedogenesis could shift $\mathrm{P}$ availability by altering acidity and the $\mathrm{Al} / \mathrm{P}$ balance.

Abbreviations: BBWM, Bear Brook Watershed in Maine; EB, East Bear; FEF, Fernow Experimental Forest; HB, Hadlock Brook; LP, Lesni Potok; MP, Mud Pond; SB, Strengbach; WB, West Bear.

Phosphorus inputs to unfertilized forest lands are largely limited to those derived from soil parent materials, with minimal inputs from precipitation (Walker and Syers, 1976; Newman, 1995). In most parent materials, P occurs predominantly in apatite $\left[\mathrm{Ca}_{5}\left(\mathrm{PO}_{4}\right)_{3}(\mathrm{OH}, \mathrm{F}, \mathrm{Cl})\right]$ (Walker and Syers, 1976). Geochemical weathering in soils results in the dissolution of primary minerals, and in the case of apatite, weathering releases $P$ into the soil environment to be utilized by biota, adsorbed to $\mathrm{Al}$ and $\mathrm{Fe}$ secondary phases, precipitated as a secondary Ca phase, or leached from the ecosystem (Smeck, 1973; Crews et al., 1995). In temperate, humid forests occurring on pedogenically young, acidic soils, the majority of the $\mathrm{P}$ is associated with $\mathrm{Al}$ and Fe hydroxides (Wood et al., 1984; Fox et al., 1990; Darke and Walbridge, 2000; Kana and Kopáček, 2005; Norton et al., 2006; Sherman et al., 2006). In a study of 11 Maine lakes, Amirbahman et al. (2003) suggested that in eutrophic lakes, Fe dominated the internal $\mathrm{P}$ cycling in sediments, while in mesotrophic and oligotrophic lakes, other mechanisms including the adsorption of $\mathrm{P}$ by $\mathrm{Al}$ hydroxide probably dominated the internal P cycling. Kopáček et al. (2005) demonstrated that, in lake sediments with high $\mathrm{Al}$ concentrations, $\mathrm{P}$ sorption by $\mathrm{Al}$ can be sufficient to prevent $\mathrm{P}$ release even during periods of anoxia and that under these conditions $\mathrm{Al}$ will limit lake $\mathrm{P}$ cycling. The high concentrations of secondary $\mathrm{Al}$ in soils derived from the weathering of aluminosilicate parent materials should lead to Al domination of $P$ retention mechanisms in soils as well (Walker and Syers, 1976; Likelema, 1980; Wood et al., 1984; Richardson, 1985; Schoenau et al., 1989; Beck

Soil Sci. Soc. Am. J. 74:2175-2186

Published online 21 Sept. 2010

doi:10.2136/sssaj2009.0267

Received 15 July 2009.

*Corresponding author (michael.sanclements@colorado.edu).

(C) Soil Science Society of America, 5585 Guilford Rd., Madison WI 53711 USA

All rights reserved. No part of this periodical may be reproduced or transmitted in any form or by

any means, electronic or mechanical, including photocopying, recording, or any information storage and retrieval system, without permission in writing from the publisher. Permission for printing and for reprinting the material contained herein has been obtained by the publisher. 
and Elsenbeer, 1999; Darke and Walbridge, 2000; Richardson et al., 2004; Norton et al., 2006; Sherman et al., 2006).

Both the eastern United States and Europe have been influenced by atmospheric deposition of $\mathrm{S}$ and $\mathrm{N}$ that have contributed to soil acidification during the past century (Likens et al., 1996; Fernandez et al., 2003; Watmough et al., 2005). Acidification of soils results in base cation depletion as a result of base cation exchange buffering processes (Fernandez et al., 2003). As acidification progresses, base cation exchange buffering is depleted and Al buffering becomes increasingly important, resulting in the mobilization of soil Al (Driscoll, 1985; David et al., 1991; Norton et al., 2004). We hypothesized that if Al exhibits strong controls on the accumulation of $\mathrm{P}$, the mobilization of $\mathrm{Al}$ due to acidification could alter soil $\mathrm{P}$ dynamics. This occurred at the Bear Brook Watershed in Maine (BBWM), where whole-watershed experimental acidification resulted in increased stream export of $\mathrm{Al}, \mathrm{Fe}$, and $\mathrm{P}$ during high-discharge events (Roy et al., 1999; Reinhardt et al., 2004). These hydrologic events were associated with precipitation and snowmelt, leading to soil solutions moving through shallow, relatively acidic soil flow paths, dissolving $\mathrm{Al}$ hydroxide and mobilizing the associated $\mathrm{P}$.

While $S$ deposition has declined in the United States and Europe, $\mathrm{N}$ deposition is predicted to increase globally (Galloway et al., 2004; Kopáček and Veselý, 2005). Besides contributing to soil acidification, atmospheric deposition of $\mathrm{N}$ can influence $\mathrm{P}$ cycling by reducing $\mathrm{N}$ nutrient limitations on forest vegetation and increasing the potential for P limitation (Aber et al., 1998; Gradowski and Thomas, 2006).

Evidence suggests that soil acidification can result in the mobilization and potential export of $\mathrm{Al}, \mathrm{Fe}$, and $\mathrm{P}$ from soils. Although we recognize that $\mathrm{Al}$ is important in soil $\mathrm{P}$ sorption, we have limited knowledge of the relative distribution of various chemical forms of $\mathrm{P}$ in acidic, forested mineral soils. Furthermore, we do not know which chemical forms of soil $\mathrm{P}$ are most likely to contribute to P mobilization and export during episodic or chronic acidification. Understanding these mechanisms is important to define the trajectory of change in $\mathrm{N}$ and $\mathrm{P}$ stoichiometry in soils and associated surface waters.

One approach to characterizing the phases of elements in soils is through chemical fractionation techniques. There is a large literature on the utilization of $\mathrm{P}$ fractionation techniques in soils, such as those originally developed by Chang and Jackson (1957), which provided the foundation for later modifications such as those of Hedley (1982) and Psenner et al. (1988). These techniques characterize the distribution of $\mathrm{P}$ into operationally defined, yet chemically meaningful fractions. The objectives of this study were to use $\mathrm{P}$ fractionation techniques on soils from a suite of acidic, forested watersheds to determine (i) if there was a predictability in the distributions of $\mathrm{P}, \mathrm{Al}$, and $\mathrm{Fe}$ among chemical fractions under ambient conditions in temperate forest soils, (ii) what the consequences of acidification would be for soil P, $\mathrm{Al}$, and $\mathrm{Fe}$ fractions, and (ii) if there was evidence of spatial patterns of $\mathrm{P}, \mathrm{Al}$, and $\mathrm{Fe}$ fractions relative to soil depth and distance from the stream within these watersheds.

\section{MATERIALS AND METHODS Watershed Research Sites}

This study was conducted at six humid, temperate watershed research sites in the eastern United States and Europe (Fig. 1). The study sites represented cool, temperate forested watersheds on acidic soils, each with a history of research on the biogeochemistry of watershed acidification. The watersheds were first-order stream watersheds with relatively thin soils, often $<1 \mathrm{~m}$, and minimal presence of a riparian zone.

\section{The Bear Brook Watershed in Maine}

Located in eastern Maine, the BBWM is a long-term, paired watershed acidification experiment. East Bear (EB) comprises 11.0 ha and serves as the reference watershed while West Bear (WB) is $10.3 \mathrm{ha}$, and has been treated bimonthly with $\left(\mathrm{NH}_{4}\right)_{2} \mathrm{SO}_{4}$ at the rate of $28.8 \mathrm{~kg} \mathrm{Sha}^{-1} \mathrm{yr}^{-1}$ and $25.2 \mathrm{~kg} \mathrm{~N} \mathrm{ha}^{-1} \mathrm{yr}^{-1}$ since November 1989. The mean annual temperature is $4.9^{\circ} \mathrm{C}$, ranging from -30 to $35^{\circ} \mathrm{C}$. Mean annual precipitation has been $140 \mathrm{~cm}$. Soils in both watersheds are typically coarse-loamy, isotic, frigid Typic Haplorthods formed from till. The bedrock is primarily quartzite and gneiss with granitic intrusions (Fernandez et al., 2003). Vegetation was similar in both watersheds, with higher elevations dominated by red spruce (Picea rubens Sarg.) and balsam fir (Abies balsamea L.); lower elevations were dominated by northern hardwoods, predominately American beech (Fagus grandifolia Ehrh.), sugar maple (Acer saccharum Marsh.), and red maple (Acer rubrum L.) (Norton et al., 1999).

\section{The Fernow Experimental Forest}

The Fernow Experimental Forest (FEF) is a long-term, paired watershed acidification experiment located in the Appalachian Mountains of north-central West Virginia. Watershed 4 (F4) is 34 ha and is a reference, while Watershed 3 (F3) is 39 ha and has been treated three times per year with $\left(\mathrm{NH}_{4}\right)_{2} \mathrm{SO}_{4}$ at a rate of $40.6 \mathrm{~kg} \mathrm{~S} \mathrm{ha}^{-1} \mathrm{yr}^{-1}$ and $35.4 \mathrm{~kg}$ $\mathrm{N} \mathrm{ha}^{-1} \mathrm{yr}^{-1}$ since January 1989. Mean annual temperature was $8.8^{\circ} \mathrm{C}$ and mean annual precipitation was $147 \mathrm{~cm}$ (U.S. Forest Service, 2008). Soils in both watersheds were loamy-skeletal, mixed, active, mesic Typic Dystrochrepts formed in colluvium and residuum overlying quartzose sandstone and shale (Kochenderfer, 2006). The watershed was not glaciated during the Wisconsinan. The dominant overstory vegetation consisted of American beech, black cherry (Prunus serotina Ehrh.), red maple, and red oak (Quercus rubra L.) (Edwards et al., 2002).

\section{Hadlock Brook}

The Hadlock Brook (HB) watershed is 47.2 ha and is located in Acadia National Park (ANP) in eastern Maine. The mean annual temperature for nearby Bar Harbor, ME, was $7.5^{\circ} \mathrm{C}$ and mean annual precipitation was $141 \mathrm{~cm}$ (Nelson, 2002). Soils developed from till and were predominately coarse-loamy, mixed, frigid Aquic Haplorthods (Parker et al., 2002). Vegetation in the lower watershed was dominated by red spruce and balsam fir with areas of gray birch (Betula populifolia Marsh.) (Sheehan et al., 2006).

\section{Mud Pond}

The Mud Pond (MP) watershed is located in eastern Maine. The mean annual precipitation was $111 \mathrm{~cm}$ and the mean annual tempera- 
ture was $6^{\circ} \mathrm{C}$. Soils were loamy, mixed, isotic Lithic Haplorthods and coarse loamy-skeletal, mixed, isotic Typic Haplorthods formed from till (Rustad and Cronan, 1995). The canopy was dominated by red spruce (Picea rubens Sarg.).

\section{Lesni Potok}

The 76-ha Lesni Potok (LP) watershed is approximately $30 \mathrm{~km}$ east-southeast of Prague in the Czech Republic. The mean annual temperature was $7^{\circ} \mathrm{C}$ and mean annual precipitation was $60 \mathrm{~cm}$ (Navrátil, 2003). The soils are classified as Dystrochrepts (Dystric Cambisols). The bedrock is granite. The watershed was not glaciated during the Wisconsinan. Vegetation was predominately European beech (Fagus sylvatica L.) and Norway spruce (Picea abies L.).

\section{Strengbach}

The 80-ha Strengbach (SB) watershed is in the Vosges Mountains of northeastern France. The mean annual temperature was $6^{\circ} \mathrm{C}$ with $140 \mathrm{~cm}$ of annual precipitation. The soils were classified as Dystrochrepts and Haplorthods (Fichter et al., 1998a). The bedrock is hydrothermally altered granite (Fichter et al., 1998b). The watershed was not glaciated during the Wisconsinan. Vegetation in the catchment was dominated by Norway spruce, with stands of European beech.

\section{Soil Sampling}

Soil sampling was conducted during the summers of 2005 and 2006. Four of the watersheds (HB, MP, F3, and F4) were sampled using a balanced paired transect design (Fig. 1). Within each watershed, two transects were established, originating at the stream and extending upslope to the watershed boundary perpendicular to the stream. Transects were located in areas of the watershed representative of the dominant watershed characteristics with respect to the vegetation, slope, and soils. This resulted in all samples being collected under a hardwood canopy at the FEF and under a softwood canopy at HB and MP. Sampling locations were along transects at (i) $0.1,1$, and $3 \mathrm{~m}$ from the stream, and then (ii) at four additional locations distributed evenly along the remaining extent of the transect. This resulted in a total of seven sample pedons per transect.

At the European sites (SB and LP), a similar paired transect design was used; however, one transect was more intensively sampled than the other. At SB, sampling locations along the intensive transect were located under a softwood canopy at $0.1,1$, and $3 \mathrm{~m}$, with five additional pedons distributed along the transect. The second transect at $\mathrm{SB}$ was established to study the substantial area of the watershed dominated by a hardwood canopy. This transect consisted of four sampling locations distributed along the hillslope and the transect did not intersect the stream channel. At LP, sampling locations along the intensive transect were at $0.1,1,3$, and $10 \mathrm{~m}$ from the stream, and then every $10 \mathrm{~m}$ to a

distance of $80 \mathrm{~m}$. The second transect was sampled at 1,40 , and $80 \mathrm{~m}$ from the stream. Both transects at LP were under hardwood canopies.

In all watersheds, a single pedon was excavated at each sampling point. The $\mathrm{O}$ horizons were quantitatively sampled from within a 30 - by $30-\mathrm{cm}$ frame. The $\mathrm{O}$ horizons in this study represent the whole surface horizon made up of organic soil materials and are equivalent to the sum of $\mathrm{Oa}$, Oe, and Oi horizons, sometimes referred to as L, F, and $\mathrm{H}$. The $\mathrm{E}$ horizons were not sampled for analysis because of their thin and inconsistent presence and limited chemical reactivity. Two depth increments of the underlying mineral soil were sampled to include (i) an uppermost sample that best represented the dominant pedogenic processes at the site and the mineral soil increment most vulnerable to the effects of acid deposition, and (ii) a deeper sample that represented soils that had undergone limited development. The upper sample was standardized as the 0 - to 10 -cm depth increment of the B horizon. Because several sites have $\mathrm{C}$ horizons consisting of dense basal till, the deeper increment was standardized to be the $10-\mathrm{cm}$ increment immediately above the $\mathrm{C}$ horizon. Upper mineral soils were sampled by inserting a bulb corer to a depth of $10 \mathrm{~cm}$ and removing the soil. Deep samples were collected by excavating the pedon to the $C$ horizon and sampling the $10 \mathrm{~cm}$ above the $\mathrm{C}$ horizon. At F3 and F4, deeper soils made collection of the $10 \mathrm{~cm}$ above the $\mathrm{C}$ horizon impractical and the deep increment was standardized as the 
40- to 50-cm depth increment representing the lower B horizon below the zone of maximum illuviation. In $\sim 10 \%$ of pedons, collecting the $10 \mathrm{~cm}$ above the $\mathrm{C}$ horizon was impossible or impractical because the soils were too shallow due to bedrock or obstructions. In those cases, the deepest possible 10-cm increment was collected. The mean depth for all deep mineral soil samples was $40.05 \mathrm{~cm}$, consistent with the $\sim 40$ - to 50-cm depth interval used at the FEF.

At the BBWM, a total of 12 pedons were distributed among four compartments representing two forest types on two watersheds (i.e., EB softwoods, EB hardwoods, WB softwoods, and WB hardwoods). The O horizons were sampled quantitatively by removing all the organic soil within a $30-$ by $30-\mathrm{cm}$ frame. Mineral soil depth increments sampled at the BBWM included 0 to 5,5 to 25 , and $25 \mathrm{~cm}$ to the top of the $\mathrm{C}$ horizon (i.e., the 25-C horizon) for consistency with the time series of BBWM soil studies. A grab sample of the upper $\mathrm{C}$ horizon was obtained from all pedons where possible. All other aspects of the sampling procedures at the BBWM were identical to those used at the other watersheds in this study. In this discussion, the 0 - to $5-\mathrm{cm}$ increments from the BBWM and the 0 - to $10-\mathrm{cm}$ increments from the other watersheds are referred to as the upper $\mathrm{B}$, and the 25-C increment at the BBWM and the $10 \mathrm{~cm}$ above the $\mathrm{C}$ horizon from the other watersheds are referred to as the lower $\mathrm{B}$.

\section{Soil Analysis}

Soil samples were secured in double plastic bags in the field, placed immediately in coolers on ice, and transported to the laboratory the same day. The soil samples were air dried, sieved (2-mm sieve for mineral horizons, 6-mm sieve for organic horizons), and homogenized before being subsampled for chemical analyses. The subsamples were oven dried at $105^{\circ} \mathrm{C}$ (mineral) or $70^{\circ} \mathrm{C}$ (organic) to determine the air-dried moisture content, to allow data to be expressed on an oven-dried basis. Soils from all sites were air dried and characterized for $\mathrm{pH}$, organic matter, and exchangeable cations in the $\mathrm{O}$ horizon and mineral soils as described by SanClements (2009).

\section{Phosphorus Fractionation}

Soil samples were analyzed using a modified version of the sequential P fractionation method developed by Psenner et al. (1988). In our study, modifications included extracting with $1 \mathrm{~mol} \mathrm{~L}^{-1} \mathrm{NH}_{4} \mathrm{Cl}$ in the first fraction rather than $\mathrm{H}_{2} \mathrm{O}$, and using $0.1 \mathrm{~mol} \mathrm{~L}^{-1}$ instead of $1 \mathrm{~mol} \mathrm{~L}^{-1}$ $\mathrm{NaOH}$ solution in the third fraction (Likelema, 1980; Wilson, 2008). One-gram soil samples were sequentially extracted into the following $\mathrm{P}$ fractions: (i) $1 \mathrm{~mol} \mathrm{~L}^{-1} \mathrm{NH}_{4} \mathrm{Cl}, \mathrm{pH} 7$, moderately shaken at $25^{\circ} \mathrm{C}$ for $1 \mathrm{~h}$, considered the exchangeable fraction $\left(\mathrm{P}_{\mathrm{NH} 4 \mathrm{Cl}}\right)$; (ii) $0.11 \mathrm{~mol} \mathrm{~L}^{-1}$ $\mathrm{NaHCO}_{3}-\mathrm{Na}_{2} \mathrm{~S}_{2} \mathrm{O}_{4}(\mathrm{BD})$ moderately shaken at $40^{\circ} \mathrm{C}$ for $30 \mathrm{~min}$, considered $\mathrm{P}$ adsorbed by reducible metal hydroxide $\left(\mathrm{P}_{\mathrm{BD}}\right)$ and thought to be primarily Fe-bound $\mathrm{P}$; (iii) $0.1 \mathrm{~mol} \mathrm{~L}^{-1} \mathrm{NaOH}$ moderately shaken at $25^{\circ} \mathrm{C}$ for $16 \mathrm{~h}$, considered $\mathrm{P}$ predominately associated with Al hydroxide and organic $\mathrm{P}$ phases, as well as some Fe hydroxide $\mathrm{P}\left(\mathrm{P}_{\mathrm{NaOH}-25}\right)$; (iv) $0.5 \mathrm{~mol} \mathrm{~L}^{-1} \mathrm{HCl}$ moderately shaken at $25^{\circ} \mathrm{C}$ for $16 \mathrm{~h}$, considered to be acid-soluble primary mineral $\mathrm{P}$ as apatite $\mathrm{P}\left(\mathrm{P}_{\mathrm{HCl}}\right) ;(\mathrm{v}) 1 \mathrm{~mol} \mathrm{~L}^{-1}$ $\mathrm{NaOH}$ moderately shaken at $85^{\circ} \mathrm{C}$ for $24 \mathrm{~h}$, considered to be the refractory and residual $\mathrm{P}\left(\mathrm{P}_{\mathrm{NaOH}-85}\right)$. Moderate shaking was achieved by placing samples in centrifuge tubes on racks in a Thermo Scientific Precision
Dubnoff shaking water bath (Thermo Scientific, Waltham, MA) and shaking at medium speed for the times noted. The $\mathrm{P}_{\mathrm{NaOH}-25}$ extract was split and an aliquot was analyzed for $\mathrm{PO}_{4}$, defined by Psenner et al. (1988) as "reactive P" $\left(\mathrm{P}_{\mathrm{NaOH} 25 \mathrm{r}}\right)$, using the molybdate-blue spectrophotometric method (Murphy and Riley, 1962). The difference between total $\mathrm{P}_{\mathrm{NaOH}-25}$ and $\mathrm{P}_{\mathrm{NaOH} 25 \mathrm{r}}$ was termed $\mathrm{P}_{\mathrm{NaOH} 25 n \mathrm{n}}$, nonreactive $\mathrm{P}$, which is thought to represent primarily organic P (Psenner et al., 1988; Psenner and Pucsko, 1988). All extractions were centrifuged at $3000 \times g$ for $15 \mathrm{~min}$ and filtered through Whatman no. 42 filter paper (Whatman Inc., Clifton, NJ). Extractions were then repeated with an agitation time of $1 \mathrm{~min}$ to rinse the samples. All fractionation runs contained reagent blanks and sample replication to assure data quality. The symbols used and fractions they represent are summarized in the Appendix. All extracts were analyzed for $\mathrm{P}, \mathrm{Al}, \mathrm{Fe}$, and $\mathrm{Ca}$ by inductively coupled plasma atomic emission spectrometry.

\section{Exposed and Occluded Apatite}

A subset of samples from the BBWM, MP, FEF, LP, and SB were analyzed a second time using a further modification of the Psenner fractionation. This modification sought to gain additional insight into the amount of apatite occluded by the mineral matrix. The initial $\mathrm{P}_{\mathrm{HCl}}$ extraction was followed by drying and pulverization of the sample with mortar and pestle until the entire sample passed through a $250-\mu \mathrm{m}$ sieve, and then re-extracted with $0.5 \mathrm{~mol} \mathrm{~L}^{-1} \mathrm{HCl}$ and moderately shaken at $25^{\circ} \mathrm{C}$ for $16 \mathrm{~h}\left(\mathrm{P}_{\mathrm{HCl} \text {-pulv }}\right)$. All extracts were analyzed for $\mathrm{P}, \mathrm{Al}$, and $\mathrm{Fe}$ as described above.

\section{Total Digestions}

A subset of 15 soil samples was randomly selected from BBWM, $\mathrm{MP}$, and HB and analyzed to evaluate the efficacy of recovery in the Psenner fractionation by comparing the sum of the sequential Psenner fractions $\left(\mathrm{P}_{\text {Sum }}\right)$ to the results of total sample digests $\left(\mathrm{P}_{\mathrm{HF}}\right)$. Digestions were performed on 0.25 -g samples of air-dry soil using $8 \mathrm{~mL}$ of $\mathrm{HNO}_{3}$ and $2 \mathrm{~mL}$ of HF, which were added to the soil in a $20-\mathrm{mL}$ Teflon screwcap vial. Samples were then gently heated (below boiling) for $8 \mathrm{~h}$ and evaporated to near dryness. The same digestion steps were repeated until complete dissolution was achieved. Following dissolution, $5 \mathrm{~mL}$ of $8 \mathrm{~mol} \mathrm{~L}^{-1} \mathrm{HNO}_{3}$ was added and evaporated to dryness to drive off any remaining HF. The remaining residue was dissolved in $10 \mathrm{~mL}$ of concentrated $\mathrm{HNO}_{3}$ over gentle heat, cooled, and diluted to $50 \mathrm{~mL}$ for analysis (Eaton et al., 1995). Samples were analyzed for total P, Al, and Fe as described above.

\section{Statistical Analysis}

Data were logarithmically transformed to meet the assumptions of normality and constant variance. In instances where logarithmic transformations failed to result in constant variance, weighted least squares (1/variance) was used before ANOVA. Post-hoc pairwise comparisons were made using Tukey's honestly significant difference. Then $\mathrm{P}_{\mathrm{NH} 4 \mathrm{Cl}}$ and $\mathrm{P}_{\mathrm{BD}}$ data required nonparametric analysis by the Kruskal-Wallis test. Comparisons between treated and reference watersheds were calculated using two-sample $t$-tests. Grand mean comparisons between upper and lower B horizons were conducted using two-sample $t$-tests. Regressions between $\mathrm{P}_{\text {Sum }}$ and $\mathrm{P}_{\mathrm{HF}}$ were conducted using a general 
linear model; data conformed to the assumptions of normality and variance. Statistical significance was designated at an $\alpha$ level of 0.05 . Statistical analyses were conducted using SYSTAT version 12.0 (Systat Software, Chicago).

\section{RESULTS AND DISCUSSION}

Table 1 shows the means for measures of organic matter (as loss-on-ignition) and the acid-base status of the soils in this study. Mean $\mathrm{O}$ horizon $\mathrm{pH}$ in $\mathrm{CaCl}_{2}$ ranged from 3.02 to 3.42 . Upper $\mathrm{B}$ horizon $\mathrm{pH}$ in $\mathrm{CaCl}_{2}$ ranged from 3.35 to 3.79 and increased with depth to a range of 3.77 to 4.33 in the lower $\mathrm{B}$ horizon. The loss-on-ignition decreased dramatically from the $\mathrm{O}$ horizon to the mineral soil and decreased with depth in the $\mathrm{B}$ horizon. The low base saturation in the mineral soil reflects the prevalence of $\mathrm{Al}$ on the exchange complex. The narrow range in $\mathrm{pH}$ and base saturation in both the forest floor and mineral soils across sites suggests a relatively narrow range in soil acidity common to these cool, temperate forest soils.

The upper B horizon typically best represents the dominant pedogenic processes in these soils. To study soil $\mathrm{P}$ fractions in the most pedogenically developed part of the solum, the upper $B$ horizon increment was sampled across all sites to compare fractionation results among watersheds. Mean P, Al, and Fe concentrations from the fractionation analyses for the upper $\mathrm{B}$ horizons from all watersheds, excluding the experimentally acidified watersheds (i.e., WB and F3), are given in Table 2. The concentrations of $\mathrm{P}, \mathrm{Al}$, and $\mathrm{Fe}$ in all fractions were commonly significantly different among the upper $\mathrm{B}$ horizons. The $\mathrm{P}_{\text {Sum }}$ concentrations represent the sum of all sequential fractions and should be nearly equivalent to the total soil $\mathrm{P}$. The $\mathrm{P}_{\text {Sum }}$ concentrations ranged fourfold among the six watersheds, from $6 \mathrm{mmol} \mathrm{kg}^{-1}$ at MP to $26 \mathrm{mmol} \mathrm{kg}^{-1}$ at SB. Comparing these differences in $\mathrm{P}_{\text {Sum }}$ to the results in Table 2 for $\mathrm{P}_{\mathrm{HCl}}$, operationally defined as a measure of primary mineral apatite $\mathrm{P}$, leads us to conclude that the range in $\mathrm{P}_{\text {Sum }}$ was strongly linked to the concentrations of apatite in the parent material. That is, the sites with high $\mathrm{P}_{\text {Sum }}$ tend to have high values of $\mathrm{P}_{\mathrm{HCl}}$ (Table 2 ). Although deep $\mathrm{C}$ horizon materials were not collected at all sites, a few $\mathrm{C}$ horizon samples were collected at the BBWM $(n=12), \operatorname{LP}(n=1)$, and SB $(n=1)$. The $\mathrm{P}_{\mathrm{HCl}}$ data from SB imply high parent material $\mathrm{P}$ concentrations (349 mmol kg-1) compared with the BBWM (86 mmol kg-1) and LP (38 mmol kg-1). These concentrations were reflected in the greater $\mathrm{B}$ horizon $\mathrm{P}_{\mathrm{HCl}}$ concentrations at $\mathrm{SB}$ and $\mathrm{EB}$ relative to LP.

Although there were notable differences in total P concentrations (Table 2) among the six watersheds, the relative distribution of the soil $\mathrm{P}$ fractions for any given watershed were remarkably similar. Figure 2 shows the grand mean (all pedons) relative distribution of $\mathrm{P}$, by fraction, for the upper $\mathrm{B}$ horizons of all untreated watersheds, which was also relatively the same for any one of the individual sites. The available $\mathrm{P}_{\mathrm{NH} 4 \mathrm{Cl}}$ fraction was the lowest concentration, with a mean across all upper B horizons of $0.12 \mathrm{mmol} \mathrm{kg}^{-1}$. The $\mathrm{P}_{\mathrm{NH} 4 \mathrm{Cl}}$ fraction is considered the most biologically available fraction, and low concentrations of
Table 1. Grand means (all pedons) for selected soil characteristics for the $\mathbf{O}$ and upper and lower $B$ horizons. Data from SanClements (2009).

\begin{tabular}{|c|c|c|c|}
\hline Watershed & $\mathrm{pH}\left(\mathrm{CaCl}_{2}\right)$ & Loss-on-ignition & $\begin{array}{c}\text { Base } \\
\text { saturation }\end{array}$ \\
\hline & & $\%$ & \\
\hline \multicolumn{4}{|l|}{ O horizon } \\
\hline East Bear Brook & 3.13 & 87 & 49 \\
\hline West Bear Brook & 3.15 & 79 & 33 \\
\hline Hadlock Brook & 3.07 & 83 & 42 \\
\hline Mud Pond & 3.03 & 88 & 33 \\
\hline Fernow 3 & 3.42 & 65 & 61 \\
\hline Fernow 4 & 3.02 & 84 & 41 \\
\hline Strengbach & 3.31 & 52 & 38 \\
\hline \multicolumn{4}{|l|}{ Upper B horizon } \\
\hline East Bear Brook & 3.77 & 17 & 11 \\
\hline West Bear Brook & 3.79 & 20 & 7 \\
\hline Hadlock Brook & 4.14 & 13 & 15 \\
\hline Mud Pond & 3.90 & 7 & 5 \\
\hline Fenow 3 & 3.84 & 6 & 6 \\
\hline Fernow 4 & 3.99 & 8 & 10 \\
\hline Lesni Potok & 3.39 & 3 & 16 \\
\hline Strengbach & 3.35 & 7 & 6 \\
\hline \multicolumn{4}{|l|}{ Lower B horizon } \\
\hline East Bear Brook & 4.20 & 10 & 7 \\
\hline West Bear Brook & 4.31 & 13 & 7 \\
\hline Hadlock Brook & 4.41 & 10 & 19 \\
\hline Mud Pond & 4.33 & 6 & 7 \\
\hline Fernow 3 & 3.96 & 3 & 4 \\
\hline Fernow 4 & 4.02 & 7 & 8 \\
\hline Lesni Potok & 3.77 & 2 & 47 \\
\hline Strengbach & 3.98 & 5 & 4 \\
\hline
\end{tabular}

available $\mathrm{P}$ are consistent with the reported low $\mathrm{P}$ bioavailability commonly found in the B horizons of acid, Al- and Fe-rich soils of humid temperate forests (Wood et al., 1984; Fernandez and Struchtemeyer, 1985; Yanai, 1992; Sherman et al., 2006). On a percentage basis, the $\mathrm{P}_{\mathrm{NH} 4 \mathrm{Cl}}$ fraction contributed only $1 \%$ of the $\mathrm{P}_{\text {Sum }}$ in the upper B horizons of these soils, compared with $72 \%$ for the largest fraction, which was $\mathrm{P}_{\mathrm{NaOH}-25}$. The dominance of the $\mathrm{P}_{\mathrm{NaOH}-25}$ fraction (which also contains a large amount of organic $\mathrm{P}$ and some Fe-P) relative to the other fractions underscores the importance of $\mathrm{Al}$ in $\mathrm{P}$ retention. The concentrations of $\mathrm{Al}$ and $\mathrm{P}$ paralleled each other in their distribution by fraction, following the sequence $\mathrm{NaOH}-25>\mathrm{NaOH}-85>\mathrm{HCl}>\mathrm{BD}>$ $\mathrm{NH}_{4} \mathrm{Cl}$. The distribution of Fe among fractions did not follow the same general pattern as $\mathrm{P}$ and $\mathrm{Al}$ but occurred in the order $\mathrm{BD}>\mathrm{NaOH}-25>\mathrm{HCl}>\mathrm{NaOH}-85>\mathrm{NH}_{4} \mathrm{Cl}$. The dominance of $\mathrm{Fe}$ in the $\mathrm{BD}$ fraction demonstrates the ability of the reducing agent to isolate reducible Fe from the metal-hydroxide matrix in the mineral soil and is further reflected in the low $\mathrm{Al}_{\mathrm{BD}} / \mathrm{Fe}_{\mathrm{BD}}$ ratios, which ranged from 0.023 to 0.11 . The operationally defined Al-P fraction, designated here as $\mathrm{NaOH}-25$, contained the second highest molar concentrations of $\mathrm{Fe}$, with $\mathrm{Al}_{\mathrm{NaOH}-25} / \mathrm{Fe}$ $\mathrm{NaOH}-25$ molar ratios ranging from 3 to 7 . This suggests that, although $\mathrm{Al}$ concentrations dominate in the $\mathrm{NaOH}-25$ fraction, Fe is an important component of this fraction. Therefore, the 
Table 2. Distribution of $\mathrm{P}, \mathrm{Al}$, and $\mathrm{Fe}$ by fraction $\left(\mathrm{NH}_{4} \mathrm{Cl}\right.$, labile $\mathrm{P}$; $\mathrm{BD}$, reducible $\mathrm{Fe} \mathrm{P}$; $\mathrm{NaOH}-25$, $\mathrm{Al}$ - and some Fe-P; $\mathrm{HCl}$, exposed apatite $\mathrm{P}$; $\mathrm{NaOH}-85$, refractory and residual P; Sum, sum of sequential Psenner fractions; $\mathrm{NaOH}-25 \mathrm{r}$, reactive Al-P; $\mathrm{NaOH}-25 \mathrm{nr}$, nonreactive $\mathrm{Al}-\mathrm{P}$ ) and watershed for upper $\mathrm{B}$ horizon samples. The $\mathrm{Al}$ and Fe values represent the concentrations of $\mathrm{Al}$ and Fe extracted along with $\mathrm{P}$ in each fraction.

\begin{tabular}{|c|c|c|c|c|c|c|c|c|}
\hline \multirow[b]{4}{*}{ Hadlock Brook } & $\mathrm{NH}_{4} \mathrm{Cl}$ & BD & $\mathrm{NaOH}-25$ & $\mathrm{HCl}$ & $\mathrm{NaOH}-85$ & Sum & $\mathrm{NaOH}-25 \mathrm{r}$ & $\mathrm{NaOH}-25 \mathrm{nr}$ \\
\hline & \multirow{2}{*}{\multicolumn{8}{|c|}{$\begin{array}{c}-\mathrm{mmol} \mathrm{kg}^{-1} \\
\text { Phosphorus } \\
\end{array}$}} \\
\hline & & & & & & & & \\
\hline & $0.165 \mathrm{abcdt}$ & 0.04abcd & 8.9abcd & 1.72 & 2.3 & $13.2 \mathrm{a}$ & $0.98 a$ & 7.96abc \\
\hline Mud Pond & 0.04aef & 0.07 efgh & 4.3aefg & 0.55 & 1.3 & $6.3 \mathrm{bcd}$ & $1.01 \mathrm{bcd}$ & 3.30adefg \\
\hline Fernow 4 & $0.04 \mathrm{bgh}$ & 0.09aeijk & 8.6ehij & $0.22 \mathrm{a}$ & $2.1 \mathrm{a}$ & 11.1befg & $1.73 \mathrm{ce}$ & 6.89dhi \\
\hline Strengbach & 0.29cegij & $2.75 b f i l m$ & 19.7bfhk & $1.68 \mathrm{a}$ & $1.7 \mathrm{~b}$ & 26.2aceh & 10.12abefg & 9.55ej \\
\hline Lesni Potok & $0.09 \mathrm{i}$ & $0.63 \mathrm{cgjl}$ & $4.2 \mathrm{cikl}$ & 0.58 & $1.1 \mathrm{ab}$ & $6.7 \mathrm{fhi}$ & $2.37 \mathrm{df}$ & 1.89bfhjk \\
\hline East Bear & 0.06dfhj & $0.70 \mathrm{dhkm}$ & 15.7dgjl & 0.79 & 1.8 & 19.1dgi & $1.60 \mathrm{~g}$ & $14.11 \mathrm{cgik}$ \\
\hline \multirow[t]{2}{*}{ Mean } & 0.12 & 0.72 & 10.2 & 0.92 & 1.7 & 13.8 & 2.98 & 7.29 \\
\hline & \multicolumn{8}{|c|}{ Aluminum } \\
\hline Hadlock Brook & $0.20 \mathrm{ab}$ & $8.1 \mathrm{abc}$ & 506abcd & $265 a b c$ & $120 a$ & $901 \mathrm{ab}$ & & \\
\hline Mud Pond & $0.05 \mathrm{acd}$ & 6.6de & 207aef & 98 & $110 b$ & 423 & & \\
\hline Fernow 4 & $0.28 \mathrm{e}$ & 3.9af & 190bgh & $38 a$ & 241 abcde & $475 \mathrm{~cd}$ & & \\
\hline Strengbach & $2.28 f$ & $4.6 \mathrm{gh}$ & $102 \mathrm{ci}$ & $37 \mathrm{bd}$ & $157 \mathrm{C}$ & 304ace & & \\
\hline Lesni Potok & 0.09bcefg & 1.3bdgi & 66degk & $41 \mathrm{ce}$ & $151 d$ & $260 \mathrm{bdf}$ & & \\
\hline East Bear & $0.44 \mathrm{dg}$ & 20.8cefhi & 456fhik & 83de & $100 \mathrm{e}$ & 661ef & & \\
\hline \multirow[t]{2}{*}{ Mean } & 0.56 & 7.6 & 255 & 94 & 147 & 505 & & \\
\hline & \multicolumn{8}{|c|}{ Iron } \\
\hline Hadlock Brook & $0.07 \mathrm{a}$ & $111 \mathrm{abc}$ & 85abcd & $81 \mathrm{abc}$ & $0.22 \mathrm{a}$ & 278abcd & & \\
\hline Mud Pond & $0.05 b$ & $61 \mathrm{e}$ & 39aef & 46 & $0.20 \mathrm{~b}$ & 147ae & & \\
\hline Fernow 4 & $0.09 \mathrm{c}$ & 64afg & 28bghi & $23 \mathrm{ad}$ & $0.19 \mathrm{c}$ & $117 \mathrm{bfg}$ & & \\
\hline Strengbach & 2.50abcde & 40bfh & $14 \mathrm{cgj}$ & 18be & $0.78 d$ & $77 \mathrm{cfh}$ & & \\
\hline Lesni Potok & $0.29 d$ & $60 \mathrm{ci}$ & 9dehk & 42cef & 1.60abcde & $115 \mathrm{di}$ & & \\
\hline East Bear & $0.23 \mathrm{e}$ & 205eghi & $143 \mathrm{fijk}$ & $67 \mathrm{df}$ & $0.34 \mathrm{e}$ & 416eghi & & \\
\hline Mean & 0.54 & 91 & 53 & 46 & 0.6 & 192 & & \\
\hline
\end{tabular}

† Data followed by the same letter are significantly different among watersheds.

results must be carefully considered given the operational nature of the fractionation methods. Organic $\mathrm{P}$ is the dominant form of $\mathrm{P}$ in the $\mathrm{NaOH}-25$ fraction within soils from all watersheds except LP. Upper B horizon grand mean molar ratios of $\mathrm{Al}_{\text {Sum }}$ ' $\mathrm{P}_{\text {Sum }}$ and $\mathrm{Fe}_{\text {Sum }} / \mathrm{P}_{\text {Sum }}$ ranged from 11 to 69 and 3 to 23, respectively. The molar ratio $\mathrm{Al}_{\text {Sum }} / \mathrm{Fe}_{\text {Sum }}$ ranged from 1.6 to 4.1 for the upper $\mathrm{B}$ horizon mineral soils. The higher $\mathrm{Al}$ concentrations magnify the importance of $\mathrm{Al}$ in $\mathrm{P}$ sorption in these soils. Correlations between $\mathrm{P}, \mathrm{Al}$, and $\mathrm{Fe}$ for the upper $\mathrm{B}$ horizons were consistent with the evidence for a stronger correlation for $\mathrm{P}_{\text {Sum }}$ with $\mathrm{Al}_{\text {Sum }}(r=0.55)$ than with $\mathrm{Fe}_{\text {Sum }}(r=0.16)$ in the soils.

The transect design and depth sampling used in this research allowed us to study spatial patterns of $\mathrm{P}$ fractionation. Evidence of consistent or incremental spatial patterns with distance from the stream were inconclusive and spatial patterns in the fractionation results varied widely among watersheds, and sometimes between transects within a single watershed. Therefore, there seems to be no evidence for patterns of $P$ fractions in soils with distance upslope from the streams. Despite this overall variability, generalizations can be made about chemical associations among elements. There was a clear spatial association between $P$ and $\mathrm{Al}$, with a lesser but still evident association between $\mathrm{Fe}$ and $\mathrm{P}$, and there were dramatic increases in variability in the data with proximity to the stream for the $\mathrm{B}$ horizon $\mathrm{P}, \mathrm{Al}$, and $\mathrm{Fe}$ fraction concentrations along nearly all transects.
Primary apatite is the original source of soil P that, once released, typically is retained in soils by sorption on secondary $\mathrm{Al}$ and Fe hydroxides or is biologically immobilized. The initial $\mathrm{HCl}$ extraction in this fractionation scheme is thought to extract exposed apatite $P$. In this study, we added an additional step to the fractionation scheme that included pulverization of the mineral grains after the initial $\mathrm{HCl}$ extraction, followed by an additional soil extraction with $\mathrm{HCl}$. The additional $\mathrm{P}$ recovered derived from apatite that was occluded inside mineral grains (Syers et al., 1967; Nezat et al., 2007). This protected fraction accounted for the $59 \pm 3.6 \%$ of the total apatite $\mathrm{P}\left(\mathrm{P}_{\mathrm{HCl}}+\mathrm{P}_{\mathrm{HCl} \text {-pulv }}\right)$ in the soils from the BBWM, MP, F4, LP, and SB. SanClements et al. (2009) similarly found that $49 \pm 7.0 \%$ of the total apatite $P$ was in the occluded phase in the lower $\mathrm{B}$ horizon of the $\mathrm{HB}$ watershed. The occluded apatite $\mathrm{P}$ pool is probably important for long-term ecosystem P supply and represents a significant pool of $\mathrm{P}$ that persists in these soils for some time beyond that of the exposed apatite $P$. The literature also suggests that some of the occluded apatite $\mathrm{P}$ could be more immediately available to forest vegetation through extraction and uptake by ectomycorrhizal fungi (Wallander, 1999; van Schöll et al., 2008). Understanding the $\mathrm{P}_{\mathrm{HCl}-\text { pulv }}$ pool is important to understanding $\mathrm{P}$ cycling and supply in these forests.

We compared the sum of the Psenner sequential fractions with a total soil digestion procedure $\left(\mathrm{P}_{\mathrm{HF}}\right)$ to evaluate $\mathrm{P}$ recov- 


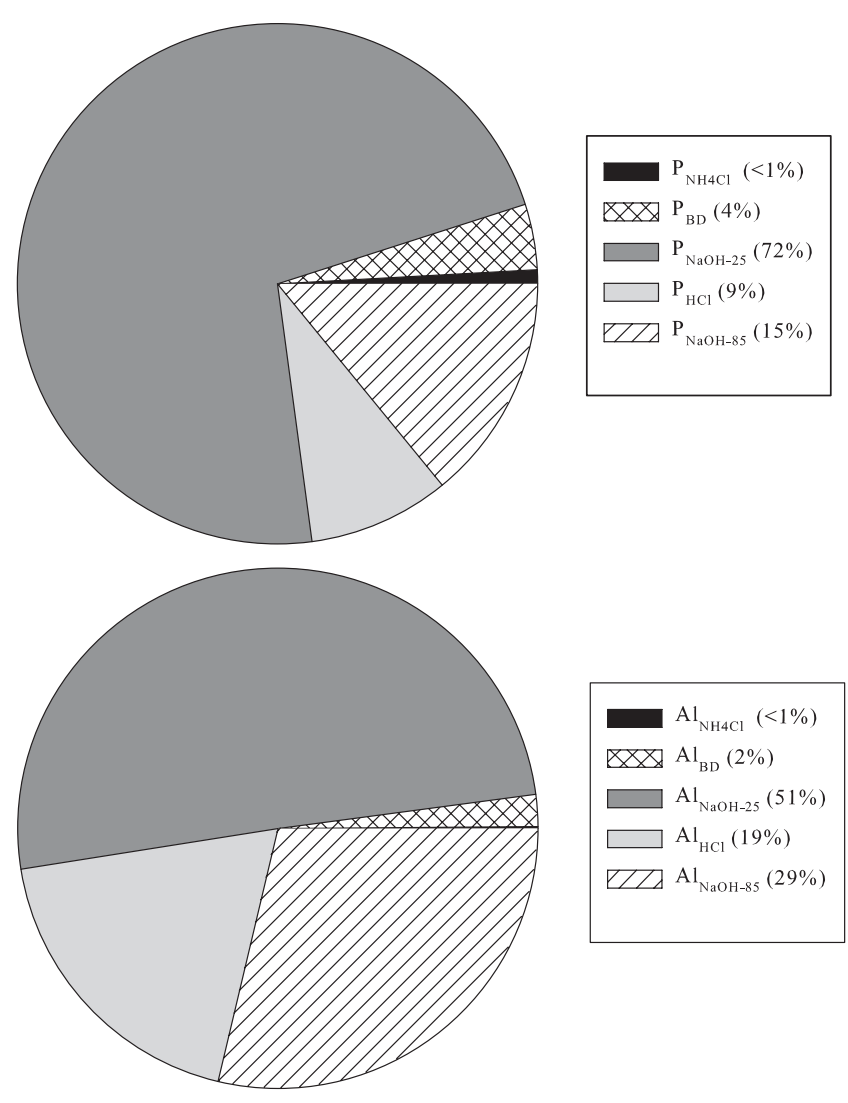

Fig. 2. Distribution of $\mathrm{P}$ and $\mathrm{Al}$ by fraction on a percentage basis $\left(\mathbf{P}_{\mathrm{NH} 4 \mathrm{Cl}}\right.$, labile $\mathbf{P} ; \mathbf{P}_{\mathrm{BD}}$, reducible Fe $\mathbf{P} ; \mathbf{P}_{\mathrm{NaOH}-25}$, $\mathrm{Al}$ - and some $\mathrm{Fe}-$ $\mathbf{P} ; \mathbf{P}_{\mathrm{HCl}}$, exposed apatite $\mathbf{P} ; \mathbf{P}_{\mathrm{NaOH}-85}$, refractory and residual $\left.\mathbf{P}\right)$. These data are upper $B$ horizon grand means on a mass basis for all watersheds in this study excluding the treated watersheds at West Bear Brook Watershed (WB) and Fernow Experimental Forest (F3).

ery. Figure 3 shows the relationship between these two measures of total $\mathrm{P}$ and how they compared with the 1:1 line. The mean recovery of $\mathrm{P}_{\text {Sum }}$ was $123 \%$ of $\mathrm{P}_{\mathrm{HF}}$, yet there was a considerable range in recovery from 64 to $212 \%$. Despite this variation between measures of total soil $\mathrm{P}$, regression analysis between $\mathrm{P}_{\text {Sum }}$ and $\mathrm{P}_{\mathrm{HF}}$ showed that these two measures of total soil $\mathrm{P}$ were highly correlated (Fig. 3). The significant positive correlation between the sum of the sequential fractionations and the total digestion procedure suggests that $\mathrm{P}$ is conserved through the fractionation and $\mathrm{P}_{\text {Sum }}$ is a reasonable measure of total soil $\mathrm{P}$.

\section{Effects of Experimental Acidification}

Two of the study sites (BBWM and FEF) included paired, whole-watershed acidification experiments with a 20-yr history of treatments at the time of this writing. Experimental acidification at both sites has led to increased export of soil base cations (Fernandez et al., 2003; Edwards et al., 2002). At BBWM, it was demonstrated that as base cationic buffering was depleted in the soils, Al buffering became the dominant acid buffering mechanism, with consequent mobilization and export of soil $\mathrm{Al}$ to the stream (Fernandez et al., 2003; Norton et al., 2004). Declining stream base cation concentrations at the BBWM have been accompanied by increased concentrations of dissolved $\mathrm{Al}$ in the treated WB from approximately $5 \mu \mathrm{mol} \mathrm{L}^{-1}$ in 1989 to concen-

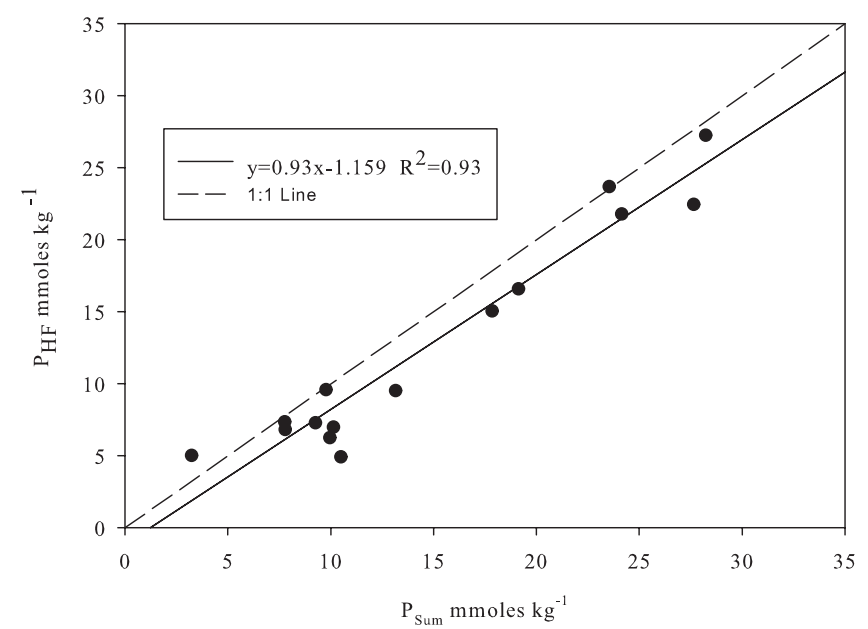

Fig. 3. The relationship between the sum of the sequential Psenner fractions $\left(\mathbf{P}_{\text {Sum }}\right)$ and the results of total sample digests $\left(\mathbf{P}_{\mathrm{HF}}\right)$ from replicates in a subsample of soils from this study.

trations commonly exceeding $40 \mu \mathrm{mol} \mathrm{L}^{-1}$ after two decades of treatment. During the same period, increases in episodic stream exports of particulate acid-soluble $\mathrm{Al}$ were even greater, ranging up to $520 \mu \mathrm{mol} \mathrm{L}{ }^{-1} \mathrm{Al}$ in WB compared with $185 \mu \mathrm{mol} \mathrm{L}-1$ in the reference EB (Norton et al., 2004). Subsequent increases in total P (mostly as acid-soluble particulate) occurred in the WB stream during high-discharge events, with increases of up to $100 \mu \mathrm{g} \mathrm{L}^{-1}$ (Norton et al., 2004; Reinhardt et al., 2004) despite base-flow P concentrations commonly being below analytical detection $\left(<0.5 \mu \mathrm{g} \mathrm{L}^{-1}\right)$. Stream water concentrations of particulate Fe increased during high flow in both the treated and reference watersheds at the BBWM, suggesting that Fe has not responded as quickly as $\mathrm{Al}$ to long-term experimental acidification. Similar evidence for chemical response during high flow has been seen in the treated watershed at FEF (Laird, 2006).

Evidence of $\mathrm{Al}$ mobilization with chronic experimental acidification at BBWM led to the hypothesis that P associated with these secondary $\mathrm{Al}$ phases might also be mobilized, potentially leading to a transient period of increased $P$ availability and ultimately net $\mathrm{P}$ depletion in the soil. To examine the evidence for this hypothesis, we compared soil $\mathrm{P}, \mathrm{Al}$, and Fe fractions from the reference and experimentally acidified watersheds at BBWM and FEF. Figure 4 depicts differences in soil P concentrations by fraction between the treated and reference watersheds at BBWM and FEF. The $\mathrm{P}_{\mathrm{NaOH}-25}$ fraction, which is predominately $\mathrm{P}$ associated with secondary soil $\mathrm{Al}$ and organic phases, dominated the pool of $\mathrm{P}$ in these soils at both sites and appeared most susceptible to mobilization by acidity. As acidification mobilized secondary $\mathrm{Al}$, it appears that $\mathrm{P}$ associated with this $\mathrm{Al}$ was simultaneously mobilized and concentrations decreased with time. Both the $\mathrm{A}$ horizon and 0 - to $10-\mathrm{cm}$ increment of the $\mathrm{B}$ horizon in F3 had significantly lower concentrations of $\mathrm{P}_{\mathrm{NaOH}-25}$ relative to the reference watershed F4 (Fig. 4). Experimental acidification on F3 at FEF was associated with a $30 \%$ lower concentration of $\mathrm{P}_{\mathrm{NaOH}-25}$ in the A horizon and a $20 \%$ lower concentration of $\mathrm{P}_{\mathrm{NaOH}-25}$ in the 0 - to $10-\mathrm{cm}$ increment of the $\mathrm{B}$ horizon (Fig. 4). In both instances, where significantly lower concentrations of 


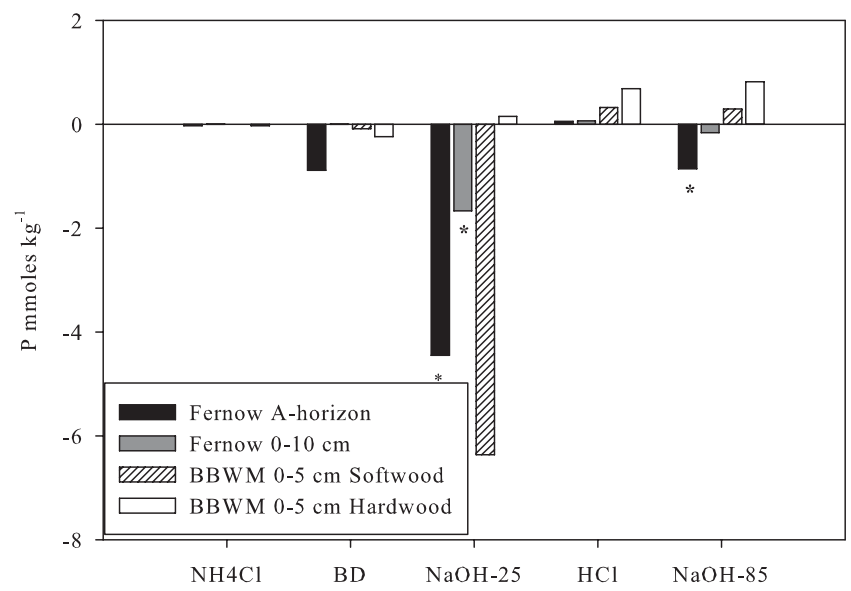

Fig. 4. Differences (treated minus reference) between $P$ fraction concentrations $\left(\mathrm{NH}_{4} \mathrm{Cl}\right.$, labile $\mathrm{P}$; $\mathrm{BD}$, reducible Fe $\mathrm{P}$; $\mathrm{NaOH}-25, \mathrm{Al}$ and some $\mathrm{Fe}-\mathrm{P} ; \mathrm{HCl}$, exposed apatite $\mathrm{P} ; \mathrm{NaOH}-85$, refractory and residual $P$ ) by site (Fernow Experimental Forest), and by site and forest type (The Bear Brook Watershed in Maine [BBWM]). Values below the line suggest decreased concentrations associated with the experimental treatments. Asterisks indicate significant differences between treated and reference watersheds at $\alpha=0.05$. The difference shown for BBWM softwoods was significant at $\alpha=0.20$.

$\mathrm{P}_{\mathrm{NaOH}-25}$ occurred, they were accompanied by significantly lower concentrations of $\mathrm{Al}_{\mathrm{NaOH}-25}$ in the treated watersheds. The $\mathrm{Fe}_{\mathrm{NaOH}-25}$ decreased by $10 \%$ in the A horizon with treatment, and increased by $17 \%$ in the 0 - to $10-\mathrm{cm}$ increment of the $\mathrm{B}$ horizon. The A horizon in $\mathrm{F} 3$ also exhibited a significant decrease in the $\mathrm{P}_{\mathrm{NaOH}-85}$ fraction. This fraction is thought to contain more highly crystalline $\mathrm{Al}$ hydroxide and associated $\mathrm{P}$. The persistence of this fraction through previous steps, and the characteristics of the extract, indicate the presence of recalcitrant $\mathrm{Al}$ hydroxide. The mean concentrations in the $\mathrm{P}_{\mathrm{NaOH}-85}$ extract were 151 and $0.5 \mathrm{mmol} \mathrm{kg}{ }^{-1}$ for $\mathrm{Al}$ and $\mathrm{Fe}$, respectively, demonstrating that the majority of the $\mathrm{P}$ was associated with Al. The 0 - to $10-\mathrm{cm}$ increment of the B horizon in $\mathrm{F} 3$ was not significantly different in $\mathrm{P}_{\mathrm{NaOH}-85}$ (Fig. 4), which may reflect the limited exposure of the upper $\mathrm{B}$ horizons to the treatment relative to $\mathrm{A}$ horizons (Bache, 1984; Pellerin et al., 2002; Norton et al., 2006). The $\mathrm{P}_{\mathrm{NaOH}-25}$ fraction from the 0 - to $5-\mathrm{cm}$ increment in WB softwoods was $45 \%$ lower than the $\mathrm{P}_{\mathrm{NaOH}-25}$ fraction in the $\mathrm{EB}(P=0.20)$ (Fig. 4). The concentrations of $\mathrm{Al}_{\mathrm{NaOH}-25}$ and $\mathrm{Fe}_{\mathrm{NaOH}-25}$ were numerically lower, but not significantly, in the treated watershed by 22 and 28\%, respectively. The similar increases in stream $\mathrm{Fe}$ concentrations during high flow in both the EB and WB (Reinhardt et al., 2004) suggest that export of Fe-associated P would be similar in both watersheds but undetectable in these experimental data. As in-stream concentrations of $\mathrm{Fe}$ did not change with treatment but did increase at high flow, the difference in $\mathrm{Fe}_{\mathrm{NaOH}-25}$ could reflect a preexisting difference between the EB and WB. Alternatively, Fe mobilization could be more controlled by redox (and thus flow) than by small changes in $\mathrm{pH}$. Furthermore, the small amount of $\mathrm{P}_{\mathrm{BD}}$ relative to $\mathrm{P}_{\mathrm{NaOH}-25}$ in the soils of the reference watershed indicates that little of the mobilized $\mathrm{P}$ was probably associated with Fe hydroxide.

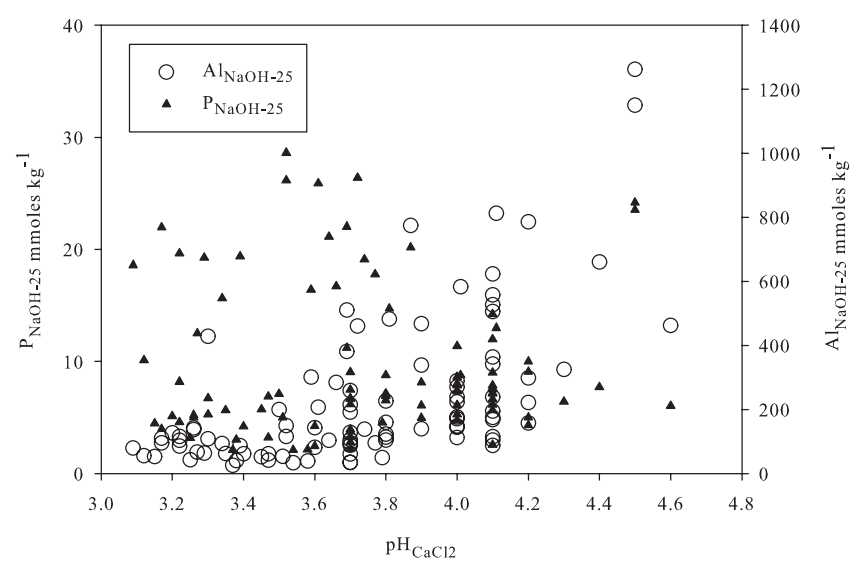

Fig. 5. The $\mathrm{Al} / \mathrm{P}$ ratio from the $\mathrm{NaOH}-25$ fraction $\left(\mathrm{Al}_{\mathrm{NaOH}-25} / \mathrm{P}_{\mathrm{NaOH}-25}\right)$ plotted against $\mathrm{pH}$ from all upper $\mathrm{B}$ horizon increments analyzed (HB, Hadlock Brook; MP, Mud Pond; F3, Fernow Experimental forest, treated; F4, Fernow Experimental Forest, reference; SB, Strengbach; LP, EB, East Bear Brook Watershed; WB, West Bear Brook Watershed). The $\mathrm{Al}$ and $\mathrm{P}$ from the $\mathrm{NaOH}-25$ fraction are considered to be extracted from $\mathrm{Al}$ hydroxide or $\mathrm{P}$ associated with $\mathrm{Al}$ hydroxide and organic P phases, as well as some Fe hydroxide P.

Experimental acidification did not result in lower $\mathrm{P}_{\mathrm{NaOH}-25}$ (Fig. 4) or $\mathrm{Al}_{\mathrm{NaOH}-25}$ in the soils from the 0 -a to 5 -cm increment of the $\mathrm{B}$ horizons under the hardwood canopy at BBWM. Although differences in the mean $\mathrm{pH}$ were not sufficient to explain the mobilization of $\mathrm{P}_{\mathrm{NaOH}-25}$ and $\mathrm{Al}_{\mathrm{NaOH}-25}$ from soils under hardwoods in the treated watersheds at FEF but not BBWM (Table 1), the soils from FEF (i.e., F3) appear to have exhibited a greater and more uniform difference in $\mathrm{pH}$ with treatment compared with BBWM (i.e., the WB) (Fig. 5). This greater apparent decrease in $\mathrm{pH}$ with treatment at FEF could reasonably result in the increased mobilization of $\mathrm{Al}$ under the $\mathrm{F} 4$ hardwoods, while the more variable and less evident $\mathrm{pH}$ effects under the WB hardwoods might not have been sufficient to mobilize $\mathrm{Al}_{\mathrm{NaOH}-25}$ and $\mathrm{P}_{\mathrm{NaOH}-25}$ from those soils.

Despite differences in forest type response by site, these data lend support to the hypothesis that chronic acidification can mobilize P due to acidified solutions moving through shallow soil flow paths where $\mathrm{Al}$ hydroxide is dissolved, thereby mobilizing the associated $\mathrm{P}$.

\section{Linkages between Soil Phosphorus and Phosphorus Availability to Biota}

Kopáček et al. (2005) investigated geochemical controls on water column P concentrations in lakes in the Czech Republic and demonstrated the dominance of $\mathrm{Al}$ in controlling water column $\mathrm{P}$ availability and sediment $\mathrm{P}$ sorption. They used similar chemical fractionation methods as used in this study, except that in the first extraction for available $\mathrm{P}$ they used water rather than $\mathrm{NH}_{4} \mathrm{Cl}$, and $1 \mathrm{~mol} \mathrm{~L}^{-1} \mathrm{NaOH}$, instead of $0.1 \mathrm{~mol} \mathrm{~L}^{-1} \mathrm{NaOH}$ in the third extraction. They used the proportions of sediment $\mathrm{Al}, \mathrm{Fe}$, and $\mathrm{P}$ as predictors of water column $\mathrm{P}$ concentrations because $\mathrm{Al}$ and Fe exert such strong controls on $\mathrm{P}$ mobility in sediments. Their results showed that in sediments with a molar ratio of $\mathrm{Al}_{(\mathrm{H} 2 \mathrm{O}+\mathrm{BD}+\mathrm{NaOH}-25)} /$ $\mathrm{Fe}_{(\mathrm{H} 2 \mathrm{O}+\mathrm{BD}+\mathrm{NaOH}-25)}>3$ and $\mathrm{Al}_{\mathrm{NaOH}-25} / \mathrm{P}_{(\mathrm{H} 2 \mathrm{O}+\mathrm{BD})}>25$, anox- 


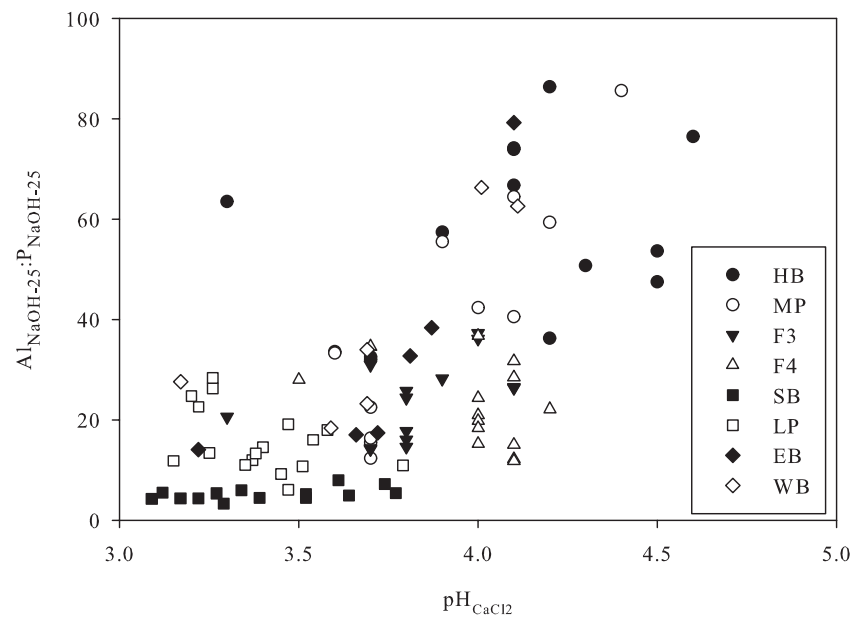

Fig. 6. The $P$ and $\mathrm{Al}$ from the $\mathrm{NaOH}-25$ fractions $\left(\mathbf{P}_{\mathrm{NaOH}-25}\right.$ and $\mathrm{Al}_{\mathrm{NaOH}-25}$, respectively) as a function of $\mathrm{pH}$ for all upper $\mathrm{B}$ horizon samples in this study. The $\mathrm{NaOH}-25$ fraction is considered to be extracted from $\mathrm{Al}$ hydroxide or $\mathrm{P}$ associated with $\mathrm{Al}$ hydroxide and organic $\mathbf{P}$ phases, as well as some Fe hydroxide $\mathrm{P}$.

ia no longer resulted in P release from sediments. They interpreted this to mean that $\mathrm{Al}$ will dominate the $\mathrm{P}$ chemistry in lake sediments when sediment $\mathrm{Al}$ concentrations significantly exceed $\mathrm{Fe}$ or $\mathrm{P}$ concentrations. This is particularly important during periods of anoxia when Fe-bound P would otherwise be released to the water column but is irreversibly adsorbed by $\mathrm{Al}$ in the sediments (Norton et al., 2006). In this study of soil $P$ fractions, we applied a similar approach to evaluating the interaction of $\mathrm{Al}$ and $\mathrm{Fe}$ with $\mathrm{P}$, but substituted the $\mathrm{NH}_{4} \mathrm{Cl}$ fraction for the $\mathrm{H}_{2} \mathrm{O}$ fraction used by Kopáček et al. (2005), as described above. The mean $\mathrm{Al}_{(\mathrm{NH} 4 \mathrm{Cl}+\mathrm{BD}+\mathrm{NaOH}-25)^{\prime}}$ $\mathrm{Fe}_{(\mathrm{NH} 4 \mathrm{Cl}+\mathrm{BD}+\mathrm{NaOH}-25)}$ ratios for the upper $\mathrm{B}$ horizons in this study ranged from 1.0 at LP to 2.6 at $\mathrm{HB}$. These were all below the threshold of 3 proposed by Kopáček et al. (2005) for conditions that would abiotically immobilize $P$ in lake sediments. By itself, this could suggest a greater potential for P mobility if these soils were exposed to reducing conditions. It is also important to note that these ratios may have been influenced by our choice of $0.1 \mathrm{~mol} \mathrm{~L}^{-1}$ $\mathrm{NaOH}$ as opposed to $1 \mathrm{~mol} \mathrm{~L}-1 \mathrm{NaOH}$. The ratio of $\mathrm{Al}_{\mathrm{NaOH}-25} /$ $\mathrm{P}_{(\mathrm{NH} 4 \mathrm{Cl}+\mathrm{BD})}$ ranged from 34 to 2483 in our soils data, however, greatly exceeding Kopáček's threshold of 25 for $\mathrm{P}$ retention by $\mathrm{Al}$ in sediments. The somewhat lower $\mathrm{Al}_{(\mathrm{H} 2 \mathrm{O}+\mathrm{BD}+\mathrm{NaOH}-25)} / \mathrm{Fe}_{(\mathrm{NH} 4 \mathrm{Cl}}$ $+\mathrm{BD}+\mathrm{NaOH}-25)$ ratio tells us that these soils have significant illuvial accumulations of both $\mathrm{Al}$ and $\mathrm{Fe}$, consistent with Spodosol development. The metal ratio tells us nothing about $\mathrm{P}$ concentrations, however, and it is evident from the ratios of $\mathrm{Al}$ to $\mathrm{P}$ (i.e., $\mathrm{Al}_{\mathrm{NaOH}-}$ ${ }_{25} / \mathrm{P}(\mathrm{NH} 4 \mathrm{Cl}+\mathrm{BD})$, which ranged from 34 to 2483 , and Fe to $\mathrm{P}$ (i.e., $\left.\mathrm{Fe}_{\mathrm{NaOH}-25} / \mathrm{P}_{(\mathrm{NH} 4 \mathrm{Cl}+\mathrm{BD})}\right)$, which ranged from 24 to 338 , that these soils have low available $\mathrm{P}$ relative to the concentrations of $\mathrm{Al}$ and $\mathrm{Fe}$ available for $\mathrm{P}$ retention. If these soils are subject to periods of anoxia during wet seasons, we expect some Fe reduction that would potentially mobilize Fe-fixed P. We hypothesize that $\mathrm{P}$ mobilized from $\mathrm{Fe}$ phases under reducing conditions would probably be irreversibly adsorbed by secondary $\mathrm{Al}$ phases because of the relatively high $\mathrm{Al}$ concentrations in these soils. This is consistent with evidence from soil solution and stream studies showing that little P escapes from

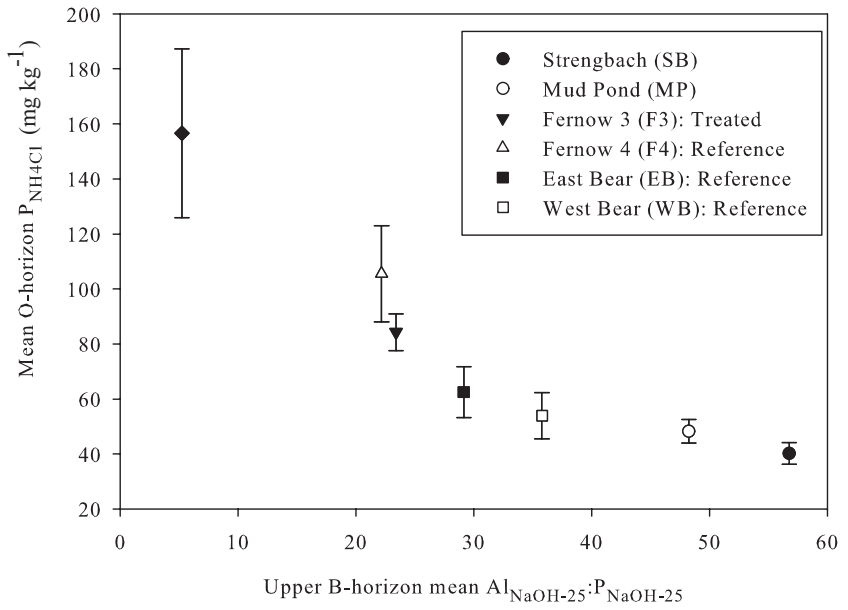

Fig. 7. The relationship between mineral soil mean $\mathrm{Al} / \mathrm{P}$ ratio from the $\mathrm{NaOH}-25$ fraction $\left(\mathrm{Al}_{\mathrm{NaOH}-25} / \mathrm{P}_{\mathrm{NaOH}-25}\right)$ and mean $\mathrm{O}$ horizon labile $\mathbf{P}\left(\mathbf{P}_{\mathrm{NH} 4 \mathrm{Cl}}\right)$ for all watersheds excluding Lesni Potok, which did not have an $\mathrm{O}$ horizon. The $\mathrm{NaOH}-25$ fraction is considered to be extracted from $\mathrm{Al}$ hydroxide or $\mathrm{P}$ associated with $\mathrm{Al}$ hydroxide and organic $\mathbf{P}$ phases, as well as some Fe hydroxide $\mathrm{P}$.

these acid, forested watersheds through leaching or stream flow, even after harvest (Wood et al., 1984; Yanai, 1992, 1998; Reinhardt et al., 2004; Norton et al., 2006), and P availability is limited (Wood et al., 1984; Yanai, 1992).

Results for sites that were experimentally acidified showed evidence of $\mathrm{Al}$ mobilization, with subsequent changes in soil $\mathrm{P}$. Therefore, we explored the relationships between soil acidity and $\mathrm{Al}$ or $\mathrm{P}$ accumulations in the suite of watersheds from this study. Because the $\mathrm{NaOH}-25$ fraction appeared to be the primary chemical phase that responded to experimental acidification, we used the ratio $\mathrm{Al}_{\mathrm{NaOH}-25} / \mathrm{P}_{\mathrm{NaOH}-25}$ to test this hypothesis.

The mobilization of $\mathrm{P}$ in soils by acid solutions appears to be driven largely by the mobilization of $\mathrm{Al}$ rather than $\mathrm{Fe}$, the latter of which has a lower solubility under acidic conditions (Drever, 1997). Figure 6 shows the relationship between the soil $\mathrm{pH}$ in $\mathrm{CaCl}_{2}$ and the $\mathrm{Al}_{\mathrm{NaOH}-25} / \mathrm{P}_{\mathrm{NaOH}-25}$ ratio for the upper $\mathrm{B}$ horizons from all pedons in this study, including the experimentally acidified watersheds. The results show that as the $\mathrm{pH}$ increased from 3.1 to 4.6, the $\mathrm{Al}_{\mathrm{NaOH}-25} / \mathrm{P}_{\mathrm{NaOH}-25}$ ratio increased from approximately 3 to 86 . Figure 6 shows the actual $\mathrm{Al}_{\mathrm{NaOH}-25}$ and $\mathrm{P}_{\mathrm{NaOH}-25}$ concentrations in these soils, with the trends in the data indicating that the relationship between the $\mathrm{pH}$ and $\mathrm{Al}_{\mathrm{NaOH}-25} / \mathrm{P}_{\mathrm{NaOH}-25}$ ratio was driven more by decreasing $\mathrm{Al}_{\mathrm{NaOH}-25}$ concentrations than by increasing $\mathrm{P}_{\mathrm{NaOH}-25}$ concentrations as the $\mathrm{pH}$ decreased. We hypothesize that the pattern of $\mathrm{Al}$ and $\mathrm{P}$ chemistry across this $\mathrm{pH}$ range results from lower rates of illuvial $\mathrm{Al}$ hydroxide accumulation in the $\mathrm{B}$ horizons at lower $\mathrm{pH}$ due to conditions favoring higher Al solubility (Drever, 1997; Norton et al., 2006). The higher anion adsorption capacity of $\mathrm{Al}$ hydroxide at the lower $\mathrm{pH}$, however, would increase the $\mathrm{P}$ retention through an increased anion adsorption capacity due to greater protonation of $\mathrm{Al}$ hydroxide (Mattingly, 1975; Kana and Kopáček, 2005; Navrátil et al., 2008). This effect would be consistent with the lower $\mathrm{Al}_{\mathrm{NaOH}-25} / \mathrm{P}_{\mathrm{NaOH}-25}$ ratio at lower $\mathrm{pH}$ values (Fig. 6) and the tendency for higher $\mathrm{P}_{\mathrm{NaOH}-25}$ at low- 
er $\mathrm{pH}$ values (Fig. 5). These data suggest that, across this population of forest soils, $\mathrm{pH}$ controls the precipitation of Al hydroxide and the ability of these soils to adsorb P.

Although this study was not designed to investigate P dynamics in both abiotic and biotic ecosystem compartments, the results offer insights into possible linkages between soil chemical properties and the biocycling of $\mathrm{P}$. Figure 7 shows the relationship between the mean upper $\mathrm{B}$ horizon $\mathrm{Al}_{\mathrm{NaOH}-25} / \mathrm{P}_{\mathrm{NaOH}-25}$ ratio and the mean $\mathrm{O}$ horizon $\mathrm{P}_{\mathrm{NH} 4 \mathrm{Cl}}$ for all watersheds in this study, including the experimentally acidified watersheds, but excluding LP where there was no $\mathrm{O}$ horizon. We used $1 \mathrm{~mol} \mathrm{~L}^{-1} \mathrm{NH}_{4} \mathrm{Cl} \mathrm{ex-}$ tractable $\mathrm{P}$ in the $\mathrm{O}$ horizon as an operationally defined measure of labile or loosely bound P (Chang and Jackson, 1957; Hieltjes and Liklema, 1980). Means are presented in Fig. 7 because subsoil fine root $\mathrm{P}$ uptake can involve a large volume of mineral soil that would transfer $\mathrm{P}$ to the forest canopy, to be returned to the soil surface through litterfall via biocycling. This mechanism of transfer from subsoils to surface $\mathrm{O}$ horizons can uncouple the linkage between surface horizons and the mineral soil immediately below in the individual pedon data.

Mean $\mathrm{O}$ horizon $\mathrm{P}_{\mathrm{NH} 4 \mathrm{Cl}}$ decreased from $156.6 \mathrm{mg} \mathrm{kg}^{-1}$ at an $\mathrm{Al}_{\mathrm{NaOH}-25} / \mathrm{P}_{\mathrm{NaOH}-25}$ ratio of 5.0 to $40.2 \mathrm{mg} \mathrm{kg}^{-1}$ at an $\mathrm{Al}_{\mathrm{NaOH}-25} / \mathrm{P}_{\mathrm{NaOH}-25}$ ratio of 56 (Fig. 7). There was some indication that $\mathrm{P}$ was increasingly labile below an $\mathrm{Al}_{\mathrm{NaOH}-25}$ / $\mathrm{P}_{\mathrm{NaOH}-25}$ ratio of approximately 35 . The highest concentrations of $\mathrm{O}$ horizon $\mathrm{P}$ occurred at sites with the lowest $\mathrm{Al}_{\mathrm{NaOH}-25}$ / $\mathrm{P}_{\mathrm{NaOH}-25}$ ratios (Fig. 6 and 7), consistent with the hypothesis that mineral soil $\mathrm{Al}_{\mathrm{NaOH}-25} / \mathrm{P}_{\mathrm{NaOH}-25}$ reflects $\mathrm{Al}$ controls on $\mathrm{P}$ availability to roots, which is ultimately expressed in $\mathrm{O}$ horizon $\mathrm{P}_{\mathrm{NH} 4 \mathrm{Cl}}$ concentrations through biocycling. Figure 6 shows that many of the lowest $\mathrm{Al}_{\mathrm{NaOH}-25} / \mathrm{P}_{\mathrm{NaOH}-25}$ ratios in the upper $\mathrm{B}$ horizons occurred at lower $\mathrm{pH}$ values. Figure 7 also shows evidence for greater $\mathrm{O}$ horizon available-P concentrations at lower $\mathrm{Al}_{\mathrm{NaOH}-25} / \mathrm{P}_{\mathrm{NaOH}-25}$ ratios, suggesting that lower mineral soil $\mathrm{pH}$ values in these ecosystems may result in greater $\mathrm{P}$ availability.

Foliar chemistry evidence from the whole-watershed acidification experiment at BBWM suggests that acidification could lead to transient increases in P availability. Elvir et al. (2005) demonstrated significant but annually inconsistent increases in foliar P concentrations in American beech and sugar maple on the treated watershed compared with the reference watershed at BBWM. These changes in foliar P concentrations could also have resulted from increased litterfall and $\mathrm{P}$ mineralization due to an ice storm in 1998. Similarly, Rustad (unpublished data, 2007) studied fine root dynamics at the BBWM and found evidence for increased $\mathrm{P}$ concentrations in live roots of $<1$ and 1 to $6 \mathrm{~mm}$ in diameter on the treated watershed. The evidence from soil and tree tissue chemistries supports the idea that experimental acidification of the mineral soils increases the bioavailability of $\mathrm{P}$, in association with increased $\mathrm{Al}$ mobilization, that persists for an undetermined period of time.

\section{CONCLUSIONS}

This study highlights the importance of $\mathrm{Al}$ in controlling $\mathrm{P}$ chemistry across a suite of acidic soils under humid, temperate forests. The results suggest that $\mathrm{Al}$ controls $\mathrm{P}$ accumulation, and that $\mathrm{Al}$ dynamics govern $\mathrm{P}$ mobility and biological availability. There is evidence that there are definable stoichiometries between $\mathrm{Al}$ and $\mathrm{P}$ that can be used to evaluate the status of $\mathrm{P}$ cycling in these forested ecosystems and that this evidence appears to be robust across both reference and experimentally acidified soils in these watersheds. Soils in the reference watersheds might be expected to persist in their current dynamic equilibrium for long time periods. Soils from the experimentally acidified watersheds could show initial responses such as P mobilization and a transient increase in P bioavailability. It is expected that this increase would not persist because chronic experimental acidification depletes more labile P-containing phases with time to achieve a new dynamic equilibrium. We would expect, however, that a legacy of this period of $\mathrm{P}$ mobilization would persist for some time after the geochemical sources of labile $\mathrm{P}$ are depleted due to biocycling in the ecosystem.

The fractionation scheme described in this research was useful in evaluating the operationally defined phases of soil P and produced surprisingly similar relative distributions among the fractions at all of the study watersheds. Absolute concentrations of the $P$ fractions varied considerably among the watersheds, with absolute concentration differences attributable to differences in parent material (till or bedrock) P concentrations. The chemical fraction of $\mathrm{P}$ associated primarily with secondary $\mathrm{Al}$ and organic phases was the dominant fraction of $\mathrm{P}$ and also appeared to be the most responsive to experimental acidification. These results provide insight into mechanisms of $\mathrm{P}$ retention in these forest soils, the importance of $\mathrm{pH}$ in defining the manner in which $\mathrm{Al}$ governs $\mathrm{P}$ dynamics, and insight into the complexity of $\mathrm{P}$ cycling in response to environmental change.

\section{APPENDIX \\ Symbols and Generic Names for Phosphorus Fractions}

$\begin{array}{ll}\mathrm{NH}_{4} \mathrm{Cl} & \text { labile } \mathrm{P} \\ \mathrm{BD} & \text { reducible Fe P } \\ \mathrm{NaOH}-25 & \mathrm{Al} \text { - and some Fe-P } \\ \mathrm{NaOH}-25 \mathrm{r} & \text { reactive Al-P } \\ \mathrm{NaOH}-25 \mathrm{nr} & \text { nonreactive Al-P } \\ \mathrm{HCl} & \text { exposed apatite } \mathrm{P} \\ \mathrm{HCl}-\text { pulv } & \text { occluded apatite P } \\ \mathrm{NaOH}-85 & \text { refractory and residual P }\end{array}$

\section{ACKNOWLEDGMENTS}

We thank the numerous individuals who contributed to this research. In particular, special thanks go to C. Spencer for help in the laboratory, B. Hoskins for assistance in analyses, W. Halteman for guidance on 
statistics, and Mary Beth Adams, Tomas Navrátil, Marie-Claire PierretNeboit, and David Manski for their permission, insight, and help in collecting the samples used in this research at various watersheds. Special thanks go to Lindsey Rustad, Tsutomu Ohno, and Aria Amirbahman for their input into this research. We acknowledge the support of the National Science Foundation Long-Term Research in Environmental Biology program (DEB-0639902), other National Science Foundation funding (DEB-0414144 and DEB-0415348), and the Maine Agricultural and Forest Experiment Station. This is Maine Agricultural and Forest Experiment Station Publ. 3117.

\section{REFERENCES}

Aber, J.D., W. McDowell, K. Nadelhoffer, A. Magill, G. Bernston, M. Kamakea, S. McNulty, W. Curry, L. Rustad, and I. Fernandez. 1998. Nitrogen saturation in temperate forest ecosystems: Hypotheses revisited. BioScience 48:921-934.

Amirbahman, A., A.R. Pearce, R.J. Bouchard, S.A. Norton, and J.S. Kahl. 2003. Relationship between hypolimnetic phosphorus and iron release from eleven lakes in Maine, USA. Biogeochemistry 65:369-386.

Bache, B.W. 1984. Soil-water interactions. Phil. Trans. R. Soc. London 305:393-407.

Beck, M.A., and H. Elsenbeer. 1999. Biogeochemical cycles of soil phosphorus in southern alpine Spodosols. Geoderma 91:249-260.

Chang, S.C., and M.L. Jackson. 1957. Fractionation of soil phosphorus. Soil Sci. Soc. Am. J. 84:133-144.

Crews, T.E., K. Kitayama, J.H. Fownes, R.H. Riley, D.A. Herbert, D. MuellerDombois, and P.M. Vitousek. 1995. Changes in soil phosphorus fractions and ecosystem dynamics across a long chronosequence in Hawaii. Ecol. Lett. 76:1407-1424.

Darke, A.K., and M.R. Walbridge. 2000. Al and Fe biogeochemistry in a floodplain forest: Implications for P retention. Biogeochemistry 51:1-32.

David, M.B., G.F. Vance, and W.J. Fasth. 1991. Forest soil response to acid and salt additions of sulfate: II. Aluminum and base cations. Soil Sci. 151:208-219.

Drever, J.L. 1997. The geochemistry of natural waters: Surface and groundwater environments. 3rd ed. Prentice Hall, Upper Saddle River, NJ.

Driscoll, C.T. 1985. Aluminum in acidic surface waters: Chemistry, transport, and effects. Environ. Health Perspect. 63:93-104.

Eaton, A.D., L.S. Clesceri, and A.E. Greenberg (ed.). 1995. Standard methods for the examination of water and wastewater. Vol. 19. Am. Public Health Assoc., Washington, DC.

Edwards, P.J., J.N. Krochenderfer, D.W. Coble, and M.B. Adams. 2002. Soil leachate response during 10 years of induced whole-watershed acidification. Water Air Soil Pollut. 140:99-118.

Elvir, J.A., L. Rustad, G.B. Weirsma, I. Fernandez, A.S. White, and G.J. White. 2005. Eleven-year response of foliar chemistry to chronic nitrogen and sulfur deposition additions at the Bear Brook Watershed in Maine. Can. J. For. Res. 35:1402-1410.

Fernandez, I.J., L.E. Rustad, S.A. Norton, J.S. Kahl, and B.J. Cosby. 2003 Experimental acidification causes soil base-cation depletion at the Bear Brook Watershed in Maine. Soil Sci. Soc. Am. J. 67:1909-1919.

Fernandez, I.J., and R.A. Struchtemeyer. 1985. Chemical characterization of soils under spruce-fir forests in eastern Maine. Can. J. Soil Sci. 65:61-69.

Fichter, J., M.-P. Turpault, E. Dambrine, and J. Ranger. 1998a. Localization of base cations in particle size fractions of acid forest soils (Vosges Mountains, N-E France). Geoderma 82:295-314.

Fichter, J., M.-P. Turpault, E. Dambrine, and J. Ranger. 1998b. Mineral evolution of acid forest soils in the Strengbach catchment (Vosges Mountains, N-E France). Geoderma 82:315-340.

Fox, T.R., N.B. Comerford, and W.W. McFee. 1990. Phosphorus and aluminum release from a spodic horizon mediated by organic acids. Soil Sci. Soc. Am. J. 54:1763-1767.

Galloway, J.N., F.J. Dentener, D.G. Capone, E.W. Boyer, R.W. Howarth, S.P. Seitzinger, et al. 2004. Nitrogen cycles: Past, present, and future. Biogeochemistry 70:153-226.

Gradowski, T., and S.C. Thomas. 2006. Phosphorus limitation of sugar maple growth in central Ontario. For. Ecol. Manage. 226:104-109.

Hedley, M. 1982. Changes in inorganic and organic soil phosphorus fractions induced by cultivation practices and laboratory incubations. Soil Sci. Soc. Am. J. 46:970-976.
Hieltjes, A.M.H., and L. Liklema. 1980. Fractionation of inorganic phosphates in calcareous sediments. J. Environ. Qual. 9:405-407.

Kana, J., and J. Kopáček. 2005. Impact of soil sorption characteristics and bedrock composition on phosphorus concentrations in two Bohemian forest lakes. Water Air Soil Pollut. 173:243-259.

Kochenderfer, J.N. 2006. Fernow and the Appalachian hardwood region. Environ. Pollut. 11:17-39.

Kopáček, J., J. Borovec, J. Hejzlar, K. Ulrich, S.A. Norton, and A. Amirbahman. 2005. Aluminum control of phosphorus sorption by lake sediments. Environ. Sci. Technol. 39:8784-8789.

Kopáček, J., and J. Veselý. 2005. Sulfur and nitrogen emissions in the Czech Republic and Slovakia from 1850 till 2000. Atmos. Environ. 39:2179-2188.

Laird, M.K. 2006. Spatial and temporal changes in stream chemistry at three watersheds during high discharge episodes. M.S. thesis. Dep. of Earth Sci., Univ. of Maine, Orono.

Likelema, L. 1980. Interaction of orthophosphate with iron(III) and aluminum hydroxide. Environ. Sci. Technol. 14:537-541.

Likens, G.E., C.T. Driscoll, and D.C. Busco. 1996. Long-term effects of acid rain: Response and recovery of a forest ecosystem. Science 272:244-246.

Mattingly, G.E.G. 1975. Labile phosphate in soils. Soil Sci. 119:369-375.

Murphy, J., and J.P. Riley. 1962. A modified single solution method for determination of phosphate in natural waters. Anal. Chim. Acta 26:31-36.

Navrátil, T. 2003. Biogeochemistry of the II.a group elements in a forested catchment. Charles Univ., Prague.

Navrátil, T., J. Rohovec, A. Amirbahman, S.A. Norton, and I.J. Fernandez. 2008. Amorphous aluminum hydroxide control on sulfate and phosphate in sediment-solution systems. Water Air Soil Pollut. 201:87-98.

Nelson, S.J. 2002. Determining atmospheric deposition inputs to two small watersheds at Acadia National Park. M.S. thesis. Dep. of Ecol. and Environ. Sci., Univ. of Maine, Orono.

Newman, E.I. 1995. Phosphorus inputs to terrestrial ecosystems. J. Ecol. 83:713-726.

Nezat, C.A., J.D. Blum, R.D. Yanai, and S.P. Hamburg. 2007. A sequential extraction to determine the distribution of apatite in granitoid soil mineral pools with application to weathering at the Hubbard Brook Experimental Forest, NH, USA. Appl. Geochem. 22:2406-2421.

Norton, S., J. Kahl, I. Fernandez, T. Haines, L. Rustad, S. Nodvin, J. Scofield, T. Strickland, H. Erickson, P. Wigington Jr., and J. Lee. 1999. The Bear Brook Watershed, Maine (BBWM), USA. Environ. Monit. Assess. 55:7-51.

Norton, S.A., I.J. Fernandez, A. Amirbahman, K. Coolidge, and T. Navrátil. 2006. Aluminum, phosphorus and oligotrophy: Assembling the pieces of the puzzle. Verh. Int. Ver. Theor. Angew. Limnol. 29:1877-1886.

Norton, S.A., I.J. Fernandez, J.S. Kahl, and R.L. Reinhardt. 2004. Acidification trends and the evolution of neutralization mechanisms through time at the Bear Brook Watershed in Maine, U.S.A. Water Air Soil Pollut. 4:289-310.

Parker, J.L., I.J. Fernandez, L.E. Rustad, and S.A. Norton. 2002. Soil organic matter fractions in experimental forested watersheds. Water Air Soil Pollut. 138:101-121.

Pellerin, B.A., I.J. Fernandez, S.A. Norton, and J.S. Kahl. 2002. Soil aluminum distribution in the near stream zone at the Bear Brook Watershed in Maine. Water Air Soil Pollut. 134:189-204.

Psenner, R., B. Bostrom, M. Dinka, K. Petterson, R. Pucsko, and M. Sager. 1988. Fractionation of phosphorus in suspended matter and sediment. Ergeb. Limnol. 30:98-103.

Psenner, R., and R. Pucsko. 1988. Phosphorus fractionation: Advantages and limits of the method for the study of sediment $\mathrm{P}$ origins and interactions. Ergeb. Limnol. 30:43-59.

Reinhardt, R.L., S.A. Norton, M. Handley, and A. Amirbahman. 2004. Dynamics of $\mathrm{P}, \mathrm{Al}$, and $\mathrm{Fe}$ during high discharge episodic acidification at the Bear Brook Watershed in Maine, U.S.A. Water Air Soil Pollut. 4:311-323.

Richardson, C.J. 1985. Mechanisms controlling phosphorus retention capacity in freshwater wetlands. Science 228:1424-1427.

Richardson, S.J., D.A. Peltzer, R.B. Allen, M.S. McGlone, and R.L. Parfitt. 2004. Rapid development of phosphorus limitation in temperate rainforest along the Franz Josef soil chronosequence. Oecologia 139:267-276.

Roy, S.J., S.A. Norton, and J.S. Kahl. 1999. Phosphorous dynamics at Bear Brooks, Maine USA. Environ. Monit. Assess. 55:133-147.

Rustad, L.E., and C.S. Cronan. 1995. Biogeochemical controls on aluminum chemistry in the O horizon of a red spruce (Picea rubens Sarg.) stand in central Maine, USA. Biogeochemistry 29:107-129.

SanClements, M.D. 2009. The chemistry of acidic soils in humid, temperate 
forested watersheds with emphasis on phosphorus, aluminum, and iron. Ph.D. diss. Univ. of Maine, Orono.

SanClements, M.D., I.J. Fernandez, and S.A. Norton. 2009. Soil and sediment phosphorus fractions in a forested watershed at Acadia National Park, Maine, USA. For. Ecol. Manage. 258:2318-2325.

Schoenau, J.J., J.W.B. Stewart, and J.R. Bettany. 1989. Forms and cycling of phosphorus in prairie and boreal forest soils. Biogeochemistry 8:223-237.

Sheehan, K.D., I.J. Fernadez, J.S. Kahl, and A. Amirbahman. 2006. Litterfall mercury in two forested watersheds at Acadia National Park, Maine, USA. Water Air Soil Pollut. 170:249-265.

Sherman, J., I.J. Fernandez, S.A. Norton, T. Ohno, and L.E. Rustad. 2006. Soil aluminum, iron, and phosphorus dynamics in response to long-term experimental nitrogen and sulfur additions at the Bear Brook Watershed in Maine, USA. Environ. Monitor Assess. 121:419-427.

Smeck, N. 1973. Phosphorus: An indicator of pedogenic weathering processes. Soil Sci. 115:199-206.

Syers, J.K., J.D.H. Williams, A.S. Campbell, and T.W. Walker. 1967. The significance of apatite inclusions in soil phosphorus studies. Soil Sci. Soc. Am. J. 31:752-756.

U.S. Forest Service. 2008. Profile of the Fernow Experimental Forest. Available at http://www.fs.fed.us/ne/parsons/fefprof.htm (verified 16 Aug. 2010).
U.S. For. Serv. Timber and Watershed Lab., Parsons, WV.

van Schöll, L., T.W. Kuyper, M.M. Smits, R. Landeweert, E. Hoffland, and N. van Breeman. 2008. Rock-eating mycorrhizas: Their role in plant nutrition and biogeochemical cycles. Plant Soil 303:35-47.

Walker, T.W., and J.K. Syers. 1976. The fate of phosphorus during pedogenesis. Geoderma 15:1-19.

Wallander, H. 1999. Uptake of P from apatite by Pinus sylvestris seedlings colonised by different ectomycorrhizal fungi. Plant Soil 218:249-256.

Watmough, S.A., J. Aherne, C. Alewell, P. Arp, S. Bailey, T. Clair, et al. 2005. Sulphate, nitrogen and base cation budgets at 21 forested catchments in Canada, the United States and Europe. Environ. Monit. Assess. 109:1-36.

Wilson, T.A. 2008. A paleolimnological assessment of three oligotrophic watersheds in Maine. M.S. thesis. Dep. of Ecol. and Environ. Sci., Univ. of Maine, Orono.

Wood, T., F.H. Bormann, and G.K. Voigt. 1984. Phosphorus cycling in an northern hardwood forest: Biological and chemical control. Science 223:391-393.

Yanai, R.D. 1992. Phosphorus budget of a 70-year-old northern hardwood forest. Biogeochemistry 17:1-22.

Yanai, R.D. 1998. The effect of whole-tree harvest on phosphorus cycling in a northern hardwood forest. For. Ecol. Manage. 104:281-295. 